\title{
Gambling (Judi Togel) in Criminology Perspective (Study in Diponegoro and Peterongan Stadium in Semarang City)
}

\author{
Novem Ollyvia Rossa ${ }^{1} \otimes$, Rizky Nurmalasari², Larasati Prameswari³, Annisa Diana \\ Savella ${ }^{4}$
}

\author{
${ }^{1}$ Crime and Society Research Study, Semarang, Indonesia \\ 2,3,4 Faculty of Law, Universitas Negeri Semarang, Indonesia \\ ⓝovem.opem@gmail.com
}

\begin{abstract}
This research analyzes about lottery gambling as one of social deviations. Togel gambling is seen as one of the forms of social pathology, where social pathology itself is defined as any form of behavior that is deemed inappropriate, violates general norms, customs, formal law or cannot be integrated into general patterns of behavior. Gambling is one of several forms of community disease that in essence is contrary to the Religion, Ethics, and Moral Pancasila, fiber is harmful to the livelihoods and lives of the people, nation and state. Therefore, the Government of Indonesia is making efforts to curb gambling, to limit it to the smallest possible environment. With various forms of gambling that are rife in people's daily lives, both overt and covert, some people tend to feel stupid and seem to view gambling as something natural, not breaking the law, so there is no need to question, even some of them argue that gambling is just a small violation. Whereas on the other hand, there is an impression from law enforcement officials who are not so serious in handling this gambling problem.
\end{abstract}

Keywords: Gambling; Criminology; Social Pathology; Togel

\section{Introduction}

Criminology (kriminologi) which in Indonesian is translated with the science of crime is $a$ and one of the disciplines of social science and is not a normative science. Criminology studies a thing called "crime" from a social perspective. In other names, Criminology is also defined as a science which in its scope studies human problems that are related to its opposition to certain social norms, so criminology can also be called a study of sociology of criminals.

Etymologically, criminology comes from the words crimen and logos, which means the science of crime. Criminology is one of the fields of scientific knowledge that has been more than 1 century old, and during that time, criminology has experienced a lot of development both from perspective, paradigm, flow or even madzab which among all of them provide a new color to the formation of concepts, theories and methods in studies criminology.

The term criminology itself was first used by P. Topinard in 1879. P. Topinard was an anthropologist from France who lived in 1830 until around 1911. From the encyclopedia, it was found that criminology was described as a science in accordance with its name, namely science who studies crime.

Meanwhile, according to Bonger, criminology is defined as science that aims to investigate the symptoms of the occurrence of 
crime in the widest scope or by it is called theoretical criminology or pure criminology which includes criminal anthropology, criminal sociology, criminal psychology, psychopathology and penology. And based on the conclusions of him in addition, practical criminology is compiled which includes criminal hygienel, criminal politics and criminalism. Theoretical criminology itself is science based on the same experience as other similar sciences, namely by observing the symptoms and then trying to investigate the causes of the symptoms (etiology) in the ways available to them.

Criminology and criminal law have different meanings, scopes, and studies. Criminology with the scope of the study includes people who commit crimes or perpetrators of crime, causes of committing crimes or motives for crime and prevention of future crimes and ways to cure people who have committed crimes.

Criminology studies crime as a social phenomenon so that as a crime behavior is inseparable in social interaction, it means that crime attracts attention because of the perceived influence of the act in human relations. If someone whose community is declared to have committed an act of evil, such an act if carried out against himself for example taking his belongings to be enjoyed, or the act is carried out on animals in a free forest, for example persecuting a wild boar that he catches, then the act is not considered evil and behavior that does not attract attention (Dirdjosisworo, 1994).

In criminology, the precautionary measures are also prioritized, which is why criminology always looks for causes of crime in the economic, social, cultural, legal and natural factors of a person. With this method, it can provide proper break through and satisfying results. Criminology is more concerned with theoretical issues that can influence the legislative body to create a law that is in accordance with a sense of community justice and also affects judges in passing verdicts on the accused.

While criminal law or criminal law is described as one of the normative disciplines or normative disciplines that study crime in terms of law or learn the rules about crime. In other words, criminology is defined as a discipline that studies the actions referred to by statutory regulations as crimes or violations, in which these offenses can be subjected to penalties in the form of criminal sanctions. Criminal law is also more concerned in terms of practice, this is because criminal law is used after the emergence of an evil act, so it emphasizes more on repressive actions.

The object of criminology in the form of people is in conflict with social norms, while the object of criminal law (violation of law and order) so that by itself also causes differences in the definition of "crime" according to criminology and according to criminal law. Because criminology as a science that stands alone in addition to criminal law, it has its own definition of what is called crime.

Criminology according to criminology is human action in opposition to some norms determined by society in the middle of human life. Crime as a human act and as a social phenomenon.

The difference that shows that criminal law is different from criminology is that criminal law focuses on proving an event of crime while criminology focuses on the factors that cause the occurrence of a crime. Criminology itself is used to express the motives of the perpetrators of crime while criminal law is aimed at the relationship between actions and their consequences (the law of causality).

One thing that has been mentioned above that the object of study in criminology but not in criminal law is social pathology or community disease. Social pathology itself is defined as any form of behavior that is deemed incompatible, violates general norms, customs, formal law or cannot be integrated into general patterns of behavior.

All of the behaviors that are called "sick" socially are social deviations that are difficult to organize, difficult to regulate and control because the perpetrators use their own methods of noncontroversial, uncommon, unusual or abnormal according to their nature. Usually they follow their own will and ways for personal gain. Because of that deviation of behavior can disturb and harm the subject of the perpetrators themselves and / or the wider community.

One form of community disease or social pathology is gambling in harmony with what has been mentioned by Bonger. Kartini Kartono also stated that gambling is a deliberate gamble; that is, risking a value or something that is considered valuable, with certain risks and expectations in the event of games, matches, competitions and events whose results are uncertain or uncertain (Kartono, 1992).

While juridically gambling and its own understanding is spelled out in Article 303 
paragraph (3) of the Criminal Code. In that article it is stated that the so-called gambling game, is each game, which in general is likely to get to depend on mere luck, also because the players are better trained or more proficient. It includes all rules regarding all decisions of the race or other games, which are not made between those who compete or play, as well as all other rules.

The definition of gambling itself is flexible and always developing. This is because gambling is influenced by the culture of each group. So that each community group has its own views or perspectives on gambling. Anton Tabah stated that gambling has become a social problem in Indonesia, even including one of the social ills that must be eradicated (Tabah, 1991). Gambling is one of several forms of community disease that in essence is contrary to the Religion, Ethics, and Moral Pancasila, fiber is harmful to the livelihoods and lives of the people, nation and state. Therefore, the Government of Indonesia is making efforts to curb gambling, to limit it to the smallest possible environment.

With various forms of gambling that are rife in people's daily lives, both overt and covert, some people tend to feel stupid and seem to view gambling as something natural, not breaking the law, so there is no need to question, even some of them argue that gambling is just a small violation. Whereas on the other hand, there is an impression from law enforcement officials who are not so serious in handling this gambling problem. Even more alarming, some gambling spots allegedly have backing from individual security forces themselves.

Therefore, to find out more about criminal acts or diseases of society in the form of gambling, the authors make observations to places where gambling is often done. The author in this case takes a sample from one form of gambling namely gambling lottery. Lottery gambling is a form of gambling that uses a lottery method that has previously been "bought" or "installed" by players both nationally and internationally. The author wants to know how gambling itself is formed, runs, and is widespread among the people. What are the motives for the perpetrators to conduct and participate in this gambling and how will the community react to the existence of social pathology in the form of gambling in their environment in accordance with the study and perspective of criminology.
Based on what has been mentioned in the background, this research analyze three main point, as follows:

1. How about perspective criminology of the phenomenon of gambling lottery that occurs in the community?

2. Apa the factors that led to the rise of lottery gambling in the community?

3. What are the benefits of criminology in the healing / eradication of lottery gambling in the community?

\section{Method}

The method is very important to determine the success of research so that it can be useful and effective in order to be able to solve the problem that will be discussed based on data that can be accounted for. The method is a way of working to understand the object of research goals and objectives.

\section{A. Research Types and Approaches}

The type of research we use is quantitative research. Qualitative research is research that is descriptive and tends to use analysis. We use a research approach with surveys. Survey research is research in a waycollect information about variables from a group of objects by visiting the scene.

The qualitative approach we use is a researcher's perspective by adopting a qualitative design in conducting studies. Qualitative research design has several characteristics, which are more general, flexible, dynamic, explorative, and experience development during the research process. In terms of data collection techniques, the qualitative approach generally adopts participatory observation techniques and in-depth interviews. The research instruments used also adjust. The bias is in the form of a notebook, a recording device, and the capacity of the researcher himself to interpret.

Analysis of research data that adopts a qualitative approach is generally inductive or a combination of both. Inductive is the process of drawing conclusions from a small case investigation in detail to get the big picture. In other words, data in the form of fragments are arranged to produce a large picture that is inferred. The 
inductive process allows the emergence of new theories in research. Authors take a direct approach to the object of research by visiting and interviewing relevant sources.

\section{B. Data Types and Sources}

1. Qualitative Data Types

Qualitative data is data that can cover almost all non-numeric data. This data can use words to describe facts and observed phenomena.

\section{Primary Data Sources}

Authors get this data is from the results of interviews with parties involved in the problems in our data.

\section{Secondary Data Sources}

Secondary data is data obtained by studying the legislation, law books, and documents relating to the issues discussed. Secondary legal material is data taken from original sources in the form of legislation that has a high authority that is binding for the implementation of community life. In this study secondary legal materials include:

a. Law No. 1 of 1946 in conjunction with Law No.73 of 1958 concerning the Imposition of the Criminal Code (KUHP).

b. Law No. 7 of 1974 concerning Control of Gambling.

c. Law No. 19 of 2016 concerning Amendments to Law Number 11 of 2008 concerning Information and Electronic Transactions.

Secondary legal materials are legal materials that provide an explanation of primary legal materials such as, draft laws, research results and opinions of legal experts.

Tertiary legal materials are legal materials that provide instructions and explanations for primary legal materials and secondary legal materials which are better known by reference names in the field of law, for example legal dictionaries, legal magazine indexes, legal research journals and research in the form of reports and legal books.

\section{Data Collection Method}

Data collection method are techniques or ways that are carried out by researchers to collect data. Data collection is carried out to obtain the information needed in order to achieve research objectives. Data collection method used in this study are:

\section{Interview}

The interview is the data collection technique was carried out through face-to-face and question and answer between researchers and speakers. We conduct structured interview techniques. The interview is structured by writing questions that will be asked to the interviewees.

\section{Observation}

Observation is a technique that is done by going directly to the place of the incident that will be carried out research. Researcher group conducts observation of non-participant observation, that is, the researcher is not directly involved in the activity of the problem or the researcher is not a suspect in the case.

\section{Research Location}

The research location is the place where the research was conducted. Determination of location is a very important stage in qualitative research, because the determination of the location of the research means that the object and destination have been set so that it makes it easier for the writer to conduct research.

In this observation, the writer chooses the location of the research in accordance with the title and object of the study. The author made observations in the Diponegoro Stadium on Jalan Ki Mangunsarkoro /Jalan Stadion Utara Semarang, Central Semarang, Central Java. The location that we go to is angkringan (cat and mouse) where in these places it is often the place where gambling takes place. As a comparison data we also made a little observation in the area of Jalan Belimbing Raya, Peterongan, South Semarang, Semarang, Central Java.

\section{Result and Discussion}

\section{A. Gambling as a Crimes in Criminology and Terminology \\ 1. Definition of Gambling}

Social deviations from a group of people or individuals will cause social problems, these events occur because of social interaction between individuals, individuals with groups, and between groups. Social interaction is based on the values of customs, traditions and ideologies that are characterized by associated social processes. The existence of deviation from their behavior towards 
the social institutions of society will cause several problems. Mismatches between the elements of cultural society can endanger this social group resulting in an imbalance of social ties in society.

If the incident continues to occur in the community, it will become a virus disrupting people's lives for example such as gambling, brawls between students and drinking. Therefore, gambling, student brawls and drinking are categorized as community ills or social ills.

In hekekat gambling is very contrary to religion, decency and moral Pancasila and endanger the community, nation and state when viewed from national interests. Gambling has a negative impact on the morale and mentality of the community, especially the younger generation. On the one hand gambling is a social problem that is difficult to overcome and the emergence of gambling has existed since the existence of human civilization. Considering the problem of gambling has become an acute disease of the community, it needs serious and systematic countermeasures (Kusuma, 1988).

Gambling according to the big Indonesian Dictionary is "Games using money as a bet" (Poerwadarminta, 1995). Gambling is "Betting an amount of money or assets in a guessing game based on chance, with the aim of getting a sum of money or assets that is greater than the original amount of money or assets" (Poerwadarminta, 1995).

Another understanding of gambling or gambling in Dutch can be seen in Fockema Andreae Legal Terms Dictionary which states as "Hazardspel or other words from Kansspel, namely gambling games, games of luck that can be punished based on existing regulations" (Algra \& Gokkel, in Adiwinata, et.al 1983; Tas, 1961).

In English gambling or narrow gambling means gamble which means "play cards or other games for money; to risk money on a future event or possible happening, and those involved in the game are called a gamester or a gambler that is, one who plays cards or other games for money "(West, 1970).

According to Kartini Kartono, gambling is deliberate gambling, which is an attempt to risk one value or something that is considered valuable by recognizing the risks and expectations of events, games, matches, competitions, and events with no or uncertain outcome (Kartono, 1981).

\section{Types of Gambling}

Government Regulation of the Republic of Indonesia Number 9 of 1981 concerning the Implementation of Law Number 7 of 1974 concerning Control of Gambling, Article 1 paragraph (1), mentions several types of gambling, namely:

The forms and types of gambling referred to in this article include:

1) Gambling at the Casino, which consists of:
a. Roulette
b. Blackjack
c. Bacarat
d. Creps
e. Keno
f. Tombala
g. Super Ping-Pong
h. Lotto Fair
i. Satan
j. Paykyu
k. Slot Machine (Jackpot)
1. Ji Si Kie
m. Big Six Wheel
n. Chuc a Cluck
o. Throw a chicken / feather on the target or board
p. The spinning (market)
q. Pachinko
r. Poker
s. Twenty one
t. Hwa-hwe
u. Kiu-Kiu

2) Gambling in crowded places includes gambling by:

a. Throw a passer or chicken feather on a board or an immovable target

b. Throw the bracelet

c. Money place (coin)

d. Coin

e. Inducement

f. Guess targets that aren't spinning

g. Throw the ball

h. Chicken fighting

i. Buffalo fighting

j. Goat or sheep fighting

k. Horse Race

1. Cow racing

m. Dog runway

n. Hailai

o. Mayong / Macak

p. Erek. 
3) Gambling that is linked with other reasons

includes gambling that is associated with habits:

a. Chicken fighting (sabung ayam)

b. Cowfighting (karapan sapi)

c. Buffalo fighting (karapan kerbau)

d. Horse Race

e. Cow racing

f. Sheep or goat fight ( $a d u$ domba)

g. Pigeon fighting (balap merpati)

In the explanation above, it is said that the form of gambling contained in number 3 , such as cockfighting, cow racing and so on, does not include gambling if the customs concerned are related to religious ceremonies and as long as the habit is not gambling.

The provisions of this article also include the forms and types of gambling that may arise in the future as long as they include the categories of gambling as referred to in Article 303 paragraph (3) of the Criminal Code.

\section{Gambling Crime Elements}

Crime is one form of "deviant behavior" that is always there and is inherent in every form of society, so that no society is free from crime. Such deviant behavior is a real threat or threat to the social norms that underlie life or social order that can cause individual tensions and social tensions, and is a real or potential threat to the ongoing social order (Arief, 2010).

According to Moeljatno himself in his book "Criminal deeds are acts that are prohibited by a law which prohibits accompanied by threats (sanctions) in the form of certain crimes, for anyone who violates the ban" (Moeljatno, 2002).

The elements or elements of a criminal offense according to Moeljatno are:

a. Conduct and consequences ( $=$ deeds).

b. Concerns or circumstances that accompany actions.

c. Additional circumstances that incriminate the criminal.

d. Elements against the objective law.

e. Elements against the law are subjective (Moeljatno, 2010).

Criminal law expert D. Simmons refers to criminal acts as Straf baar Feit as, Een strafbaar gestelde onrecht matige, met schuld verbandstaande van een keningsvat baar theory of person. Crime according to Simmons is divided into two elements namely:

a. The objective element consists of:

1) People's deeds.
2) As a result of the loss of these actions.

3) Certain circumstances that accompany these actions

b. Subjective elements:

1) People who are able to take responsibility.

2) There are mistakes that accompany the actions (Sudarto, 1990).

Gambling or gambling in Article 1 of Law Number 7 of 1974 concerning Control of Gambling is called "As a gambling crime and is identical to crime, but the definition of gambling crime is basically not clearly stated and detailed either in the Criminal Code or in Law Number 7 of 1974 concerning Control of Gambling "(Saleh, 1976).

Efforts to tackle crime by using criminal sanctions are essentially the oldest methods, as old as human civilization itself (Arief, 1998).In Law No. 7/1974 concerning Gambling Control which changes the criminal threat in Article 303 of the Criminal Code with a severe criminal threat that is ten (10) years in prison and a fine of 25 million rupiah. Although the threat of punishment has been exacerbated, there are still many people who do it. This is caused by people's desire to get as much money as possible with easy means and with little capital.

Penalties in gambling cases are regulated in Article 303 of the Criminal Code and Article 303 of the Criminal Code. in the explanation of Law Number 7 of 1974 article 1 states that there are classifications of all kinds of gambling criminal acts as crimes and burdensome penalties.

One of the provisions that formulates threats to gambling criminal acts is in articles 303 and 303 bis of the Criminal Code which have been amended in Article 2 paragraph (1), (2) and (3) of Law Number 7 of 1974. In that Article states:

1) Change the threat of punishment in article 303 paragraph (1) of the Criminal Code, from a maximum prison sentence of two years eight months or a maximum fine of Ninety thousand rupiahs to a prison sentence of ten years or a maximum of two fifty five million rupiah.

2) Change the threat of punishment in article 303 bis verse (1) of the Indonesian Criminal Code, from a maximum sentence of one month or a maximum of four thousand five hundred rupiah to a maximum of four years in prison or a maximum of ten million rupiah.

3) Change the threat of punishment in article 303 bis verse (2) of the Criminal Code, from a maximum sentence of three months or a maximum of seven thousand five hundred 
rupiahs to a maximum sentence of six years or a maximum of five twelve million rupiah (Marzuki, 2011).

One of the provisions that formulates threats to gambling crime is article 303 paragraph (1) which contains elements without permission, thus gambling can be classified into two types, namely:

1) Gambling that is not a criminal offense if the implementation has obtained prior permission from the authorized official, such as:

a. Casino and Petak Sembilan in Jakarta and Sari Empat on the Bandung temple road.

b. Toto (Totalisator) Gray Hound in Jakarta (closed October 1, 1978 by the DKI government).

c. The lottery of hope which has been turned into a Lucky Lottery Prize, the center is in Jakarta. in Surabaya there were Lottery Covers, Borobudur Covers in Solo, Lake Toba Covers in Medan, Sumber Harapan Cover in Jakarta, all with prizes of 80 million rupiah (Kartono, 2005).

\section{B. Factors Causing Togel Gambling}

Gambling is a disease of society that has existed for a long time. As one of the diseases of the community, appropriate treatment is needed to reduce it in the form of countermeasures that can be carried out on target, for that we need to know what are the causes. In the case of gambling, even though the threat of punishment has been exacerbated and the type of offense has been changed (from violation to crime), this community disease cannot be overcome.

That is partly because humans have basic needs that must be met, while on the other hand not everyone can meet these needs for various reasons, for example because they do not have work or they may have work but not enough to meet their basic needs. So they do a variety of ways to increase the shortage of these needs, including the choice of gambling and gambling, gambling becomes an alternative that must be done even though they know the risks, to meet their needs and their families.

Given the consequences arising from a very broad gambling, the Police as law enforcement have an important task and quite heavy. The police is a government agency tasked with maintaining security and public order (arresting people who violate the law) or can also be interpreted as members of a government agency (civil servants in charge of maintaining security and public order) (Kelana, 1994).

Based on the results of the study, it is known that there are many factors that cause someone to like playing gambling lottery. From some of these factors can be grouped into two factors, namely internal factors and external factors.

a. Internal factors, in general, internal factors are causes that originate within the lottery gambler, these factors include, among others, economic factors, educational factors, religious factors, and the belief in victory factors.

b. External factors, factors originating from outside the lottery gamblers themselves, these factors include, among others, social factors, environmental factors, and family factors (Widhiantara \& Suardana, 2013).

Apart from internal and external factors there are also some that can influence include:

a. Factors of Perception of Skills

A gambler who feels himself very skilled, the perpetrators feel he is very skilled and observant in putting the numbers for gambling so he is very confident he will win.

b. Economic factors

For people with low social and economic status gambling is often seen as a means to improve their standard of living. As done by the perpetrators they want to get income in a flash and with a very large nominal, when gambling they make bets as big as possible starting from Rp. 200,000, - to millions and the profits are in accordance with the money he bet.

c. Situational Factors

The perpetrators are reluctant if they do not play and there is an awkward feeling towards their peers because they do not join. The perpetrators initially only just playmates but the passage of time the individual entered into cockfight gambling.

d. Learning Factors

A person will learn a lot to get a win from the experience he can during playing gambling, this will be proven by the more he plays often, then he will get used to the patterns of existing gambling numbers.

e. Perception Factors about Victory Probability The intended perception here is the perception of the perpetrators in making an evaluation of the chances of winning that they will get if he gambles. Gamblers who have difficulty 
leaving gambling usually tend to have the wrong perception of the possibility of winning. They generally feel very confident of the victory they will get, even though in reality the opportunity is very small because the belief that there is only an illusion obtained from the evaluation of opportunities based on an uncertain situation or event and very subjective.

f. Entertainment factor

The lottery gamblers are not all middle class people, so not all of them play gambling to get more money, some of which use the gambling moment to joke (Ghoni, 2017).

\section{Legal Efforts Made by the Police to Overcome Gambling Crimes}

If we hear the word gambling, immediately it occurs to us that money is made for gambling. In the mind has been embedded an idea that gambling is a place to make money but in an illicit way. During this time the police continue to rely on efforts to prevent and control gambling lottery which is more popular in the sense that its approaches are carried out with the assistance of community cooperation.

Because only this effort is expected for all Indonesian people to be able to prevent and tackle lottery gambling that is still rife today. These efforts include prevention and repressive measures.

1) Preventive measures (prevention), preventive efforts that are intended as an effort to prevent the possibility of emergence and widespread gambling in the community, so trying to prevent someone before committing crime gambling, however prevention is still far better than cure. Prevention efforts such as conduct legal counseling to the community, form a team involving intelligence to spy on a place that is often used as a lottery gambling place, strengthen religious beliefs for each individual, and conduct patrol and guard or supervise the community.

2) Repressive efforts (countermeasures), Countermeasures are all efforts aimed at someone who has become evil to help him back the right path, so as not to repeat his actions. Countermeasures such as information from the public, investigations and investigations, ambushes, giving penalties or convicting violators, fostering in correctional institutions (Ghomi, 2017).

\section{Criminological Analysis of the phenomenon of gambling gambling that occurs in the community}

Gambling games have the following meanings: a game that is risking some money or property. Broadly all the existing games are risking some money, so it is considered gambling (Sebayang, 2005).

Gambling is a deliberate gamble that is risking a value or something that is considered to be valuable by realizing the existence of risks and expectations of certain expectations in the events of games, matches, competitions and events whose results are uncertain / uncertain (Kartono, 1979).

Criminology seeks to gain knowledge and understanding of social phenomena in the field of crimes that occur in society, or in other words why the defendant commits his evil deeds (Sahetaphy, 1982). Lottery gambling that is rife in society is a social phenomenon in the field of crime whose motives are very diverse between each individual. But in broad outline the motive is divided into 2, namely: Some individuals consider this lottery gambling game only solely for entertainment so that for them this lottery gambling activity is not a crime or a violation. However, some others make this game as a profession, especially for 'bookie lottery' which is based on the intention to earn profits.

Criminology, according to Enrico Ferri, seeks to solve the problem of crime with a positive study and social facts, crime including any actions that threaten the collective and from groups which cause a defense reaction of the community based on their own judgment (Gurvitch, 1961). Lottery gambling which is considered prevalent in the Indonesian community, especially in the city of Semarang, indeed invites great enthusiasm among the people, not only the middle to lower classes, but also according to the source, this lottery gambling is quite popular with the middle to upper classes. In fact, if examined positively, this lottery gambling game is considered as an event to prove one's fortune, but it is also profitable by only spending Rp. 1,000.00 to buy a lottery number, then someone has the opportunity to earn money in the range of Rp. $25,000.00$ to Rp. $75,000,000.00$. Thus, crime can be seen as a human action and as a social phenomenon (Utrecht, 1958).

According to Bonger, criminology is science that aims to investigate the symptoms of crime as widely as possible (theoretical or pure criminology). Based on the conclusions of him in 
addition, practical criminology is prepared. Theoretical criminology is a science based on experience which, like other similar sciences, pays attention to symptoms and seeks to investigate the causes of these phenomena (etiology) in the ways available to them. Examples of social pathology (community disease); poverty, bastard children, prostitution, homelessness, gambling, alcoholism, narcotics and suicide (Bonger, 1962). So in this case lottery gambling is included in social pathology (community disease).

Edwin $\mathrm{H}$ Sutherland and Donald $\mathrm{R}$. Cressey, criminology is "a body of knowledge regarding crime as a social phenomenon" science from various sciences that study crime (evil acts) as social phenomena. Criminology is divided into 3 (three) main branches of science, namely:

1) Sociology of law, studying crime as an act that is prohibited by law and threatened with sanctions. So what determines that an act is a crime is the rule of law; In legal sociology, the act of gambling lottery is considered a crime because it violates the rule of law and there are sanctions established by law related to the act. The legal rules governing gambling in Indonesia are Law Number 7 of 1947 concerning the Control of Gambling and Article 303 of the Criminal Code concerning Gambling Crimes.

2) Crime etiology which is a branch of criminology that seeks to conduct scientific analysis of the causes of crime. In criminology, the etiology of crime is the "most" major study. Lottery gambling, if based on the results of interviews with several informants, it is known that the cause of this crime is due to weak understanding of religion, lack of education, low economic level, environmental / customary factors, and also weak law enforcement.

3) Penology is basically the science of punishment, but Sutherland includes rights related to crime control efforts, both repressive and prefentive (Santoso \& Zulfa, 2009). Article 1 of Law No. 7/1974 concerning the Control of Gambling states that all gambling crimes are crimes. Whereas Article 2 states:

a. Change the threat of punishment in article 303 paragraph (1) of the Criminal Code, from a maximum prison sentence of two years and eight months or a maximum of ninety thousand rupiahs to a maximum of ten years in prison or a maximum of two fifty five million rupiah.

b. Change the threat of punishment in article 542 paragraph (1) of the Indonesian Criminal Code, 59 from a maximum sentence of one month or a maximum of four thousand five hundred rupiahs to a maximum of four years in prison or a maximum of ten million rupiah.

c. Change the threat of punishment in article 542 paragraph (2) of the Criminal Code, from a maximum sentence of three months or a maximum of seven thousand five hundred rupiahs to a maximum sentence of six years or a maximum of fifteen million rupiah.

d. Change the title of article 542 to article 303 bus

Criminology aims to provide clues as to how society can eradicate crime with good results and even more to avoid it (Bonger, 1962). Criminology aims to anticipate and react to all policies in the field of criminal law, so as to prevent the possibility of adverse consequences, both for the perpetrators, victims, and society as a whole (Atmasasmita, 2005). This is very reasonable because gambling is a real threat to social norms that can cause individual tensions and social tensions. In terms of national interests, all types and forms of gambling have negative and detrimental effects on the morale and mentality of the community, especially the younger generation.

Robert F. Meier believes that criminological obligations in the global era are as follows:

1) Disclose the veil of criminal law, both its sources and uses, to expose the interests of the authorities;

2) Conduct studies on social control, bureaucracy and mass media tools to expose their interrelationship in elitist ideology;

3) Proposing new crime formulations, by correcting the imbalance resulting from the elite's influence on the making of laws, also includes violations of human rights as crimes;

4) Practicing new criminological theories (in the context of praxis) by trying to change the political and economic means of existing capitalism, which is considered to be the culprit of the present situation (Meier, 1977).

Paul Moedigdo Moeliono criticized Ian Taylor and his friends (1973) and Jack Young 
(1975) stated the erroneous formulation that criminologists are obliged to try to create a society where the existence of human diversity is not a victim of the criminalization of the authorities. According to Paul Moedigdo crime must be formulated on the basis of egalitarian and cooperative principles, not based on hierarchical and exploitative principles. Individual rehabilitative correctiveism or social reforms on the surface should not be viewed a priori like those of Ian Taylor, Paul Walton and Jack Young but like forms of deviant behavior and criminological activities themselves which are judged whether politically and humanly, progressively or retrogressively (Moliono, 1976 in Japsers et al (eds), 1976; Soekanto, 1986).

\section{E. Factors That Caused the Rise of Togel Gambling in the Community}

Here are the factors of the rise of lottery gambling, including:

\section{Religion}

The role of religion is very large in shaping one's morals and personality. Basically, all religions invite and guide humans to the goodness and truth of the environment.

According to Kartono that one interesting thing is the activities carried out around this gambling, namely fortune-telling (Kartono, 1983). Why is it interesting, because it has entered magical mystical areas and this means entering the belief system area.

The lottery gambling player always imagined that there was hope for a large enough profit suddenly, and according to them the more intelligent and accustomed, a gambling player was most likely to make a profit by earning a large amount of money. This is confirmed by Kartono that betting in gambling is purely speculative in luck. This conception of chancy is more or less always an element of mystical belief in the possibility of luck.

Low understanding of religion is what makes them often underestimate sin and do not feel that their actions can be transmitted to others, especially children because gambling is done in an open and open place.

\section{The economy}

Poor people get a living that can cause people to speculate playing gambling or because of the striking difference in economic levels where one side lives completely lacking in low income while on the other hand people live in sufficiency and luxury so that it can lead to crime.

Gambling is popular with all groups of people, especially low-income people. In general, people do gambling games based on hobbies or entertainment. In addition, it is also driven by a strong desire to obtain large or multiplied profits, by betting that the victory depends on luck and also sometimes because of the skill of playing.

The research showed that at first both lottery gamblers were only interested and just wanted to try how to process the lottery gambling game. A small trader, a collector, unemployed, housewife and others who have low income and are barely sufficient for the fulfillment of their family's life tend to gamble. Someone who has a low income who wants to get rich quickly and get a large profit generally does things that are fortunate in the hope of getting a profit. This advantage is expected to be used for additional shopping or meeting other needs.

Gambling is related to the dream world that offers life in the subconscious. There are no wealthy people because of gambling, but the gambling community is very confident that with gambling they will be rich. People are never aware of this, they are only tempted to double their money when they win, without calculating the money spent every day to buy a number. When someone wins, then the news will spread everywhere so that it's as if someone easily gets a lot of money just by spending a little money. But when they lost, no one talked about this.

\section{Education}

The higher the level of one's education, the higher his intelligence will be. Higher education enables changes in behavior and reasoning of a person, so that he understands the cause and effect of what he does.

High or low level of a person's education is very influential on a person's behavior in social life. The higher one's education, the person tends to think long before doing. And conversely the lower level of one's education, a person will tend not to think long and not think about the consequences of acting and tend to do actions that violate the norms and the law. Based on the data from the interviews, it is known that the perpetrators of lottery gambling (both retailers and buyers) educated with elementary school graduates and not graduating from junior high school have a high percentage compared to the perpetrators of high school / 
equivalent or academics / equivalent. So it can be concluded that the lower the level of one's education, the greater the percentage of gambling crime. Lack of education causes one to think pragmatically and simply that is to think that if a number is placed translucent two or three numbers will get a million of money without thinking how much money is at stake in gambling, how much is the ratio of people who win with numbers that are translucent, also rarely think how much big chance between victory and fatigue. Everyone thinks of victory and victory. how big is the ratio of people who win to numbers that are translucent, also rarely think how big the odds between winning and fatigue. Everyone thinks of victory and victory. how big is the ratio of people who win to numbers that are translucent, also rarely think how big the odds between winning and fatigue. Everyone thinks of victory and victory.

According to Haryanto that poverty of science causes a person to belong to a group of people who do not have principles and convictions because it is easy to follow the direction of the wind so that it is easy to be directed at things that are not good, follow the passions and order empty dreams and endless beautiful dreams (Haryanto, 2003).

\section{Habit}

According Sudarsono that humans are social creatures, to carry out their lives must cooperate with other humans around him (Sudarsono, 2008). This is closely related to the environment in which they live. Based on available data, some retailers who are housewives do not hesitate anymore to carry out their role as registers of lottery numbers because there are no immediate family members who forbid and even participate in putting up numbers. For the number buyer himself at first he just wants to try, but out of curiosity and believes that victory can happen to anyone, including himself and believes that he will someday win or succeed, thus making him gamble repeatedly. From the statement above, there are two environments that affect the personality / soul of a person to do lottery gambling. The first is the family environment. Because in the family environment the first time someone is educated, raised, get the opportunity to meet with fellow human beings, and gain knowledge about the norms that exist in society.

The second environment is the community environment. In a social environment, a person is always in touch with other people's lives. It can be said if the neighborhood is good, it will be good for humans, but conversely, if the environment is bad or bad, the people will be bad. For example, someone who lives in an environment where the majority of the community likes to play gambling, then that person will eventually play gambling. Because both directly and indirectly someone will get used to the habits of the community to play gambling and tend to do according to their environment.

The social environment has a very big influence on the subject's desire to buy a lottery. Evidenced by the subject at first knowing the game procedures and buying lottery from his friends. News about the gamblers who managed to win gives the impression to prospective gamblers winning in gambling is a normal, easy and can happen to anyone (when in fact the possibility of winning is very small). Thus, maybe gambling is already a social disease whose age is the same age as human birth and there are still filling human needs.

\section{Weak Law Enforcement}

Laws are regulations that are binding and force people to obey them. law needs to exist to regulate human interests in society in order to obtain an orderly life. If this rule is violated there will be sanctions that are forced. The research data shows that there is no socialization / counseling about the dangers of lottery gambling and appropriate punishment for the community if found lottery gambling, so that people are no longer reluctant to gather and talk about matters related to lottery such as dreams, zodiac that apply on that day and the number that came out the most. In addition, because they often see the police involved in putting up numbers, people seem to be no longer afraid and openly gamble. This makes the lottery more widespread in the community due to the weakness of the law in dealing with the problem of gambling. In addition, the sentence sentenced by the judge is very mild. The average number of cases convicted by lottery sellers is around 3-4 months in prison. Even though the threat of law for gamblers has been regulated in article 303 of the Criminal Code with a legal threat of 10 years in prison. The low verdict of the judge does not cause a deterrent effect for the lottery sellers so they want to repeat and repeat his actions. Even though the threat of law for gamblers has been regulated in article 303 of the Criminal Code with a legal threat 
of 10 years in prison. The low verdict of the judge does not cause a deterrent effect for the lottery sellers so they want to repeat and repeat his actions. Even though the threat of law for gamblers has been regulated in article 303 of the Criminal Code with a legal threat of 10 years in prison. The low verdict of the judge does not cause a deterrent effect for the lottery sellers so they want to repeat and repeat his actions.

\section{F. The Benefits of Criminology in Healing / Eradicating Gambling Gambling in the Community}

Criminology prefers preventive actions because it is always looking for reasons for the emergence of a crime in the economic, social, cultural, legal and natural factors of a person, thereby providing the right break through and satisfying results.

In accordance with the benefits of criminology, in this case:

1) One of the basic / background knowledge for professions and social workers can use criminology in tackling the problems of the society being addressed. In this case criminology can be used as a way to deal with gambling. So that it can be known the factors that cause gambling still carried out by the public.

2) To avoid hatred or unhealthy sympathy for the perpetrators of crime.

3) Other benefits for individuals, society and science. Criminology provides input in the academic field, especially in terms of education about the science and knowledge of gambling.

The following are preventive measures that can be taken to prevent the rampant gambling of gambling in the community:

1) Conducting counseling to the public related to lottery gambling activities, that the act is a crime which if done there are legal consequences. So hopefully the public can think again before gambling gambling games.

2) Inviting the public to participate in eradicating these activities by reporting to the authorities if there is a indication that there is a place to carry out the gambling lottery activities in their environment.

3) Improving the quality of education in Indonesia, thus not many young people are trapped in the game.
4) Close or block online gambling sites, because that's where the source of the game can be easily accessed by all groups.

In addition, efforts to eradicate lottery gambling activities in a very lively community are as follows:

1. Form a special team from the police to eradicate online gambling activities that are spread in various points of the city.

2. Arrest those who are directly involved in the lottery gambling activities and are processed in the fairest possible way.

3. Supervise areas that are prone to lottery gambling to minimize the existence of other criminal acts that may arise.

4. Providing wider employment opportunities to accommodate workers in Indonesia, because based on this research the toggle players are indicated as unemployed unemployed people and making this lottery gambling a profession that is considered quite profitable.

\section{Conclusion}

Criminology is defined as science that aims to investigate the symptoms of the occurrence of crime in the widest scope or by it is called theoretical criminology or pure criminology which includes criminal anthropology, criminal sociology, criminal psychology, psychopathology and penology. And based on the conclusions of him in addition, practical criminology is compiled which includes criminal hygienel, criminal politics and criminalism.

Criminology and criminal law have different meanings, scopes, and studies. Criminology with the scope of the study includes people who commit crimes or perpetrators of crime, causes of committing crimes or motives for crime and prevention of future crimes and ways to cure people who have committed crimes.

While criminal law or criminal law is described as one of the normative disciplines or normative disciplines that study crime in terms of law or learn the rules about crime. In other words, criminology is defined as a discipline that studies the actions referred to by statutory regulations as crimes or violations, in which these offenses can be subjected to penalties in the form of criminal sanctions. 
One thing that has been mentioned above that the object of study in criminology but not in criminal law is social pathology or community disease. Social pathology itself is defined as any form of behavior that is deemed incompatible, violates general norms, customs, formal law or cannot be integrated into general patterns of behavior.

One form of community disease or social pathology is gambling. gambling games, are each game, which in general is likely to get to depend on mere luck, also because the players are better trained or more proficient. It includes all rules regarding all decisions of the race or other games, which are not made between those who compete or play, as well as all other rules.

Basically, gambling is very contrary to religion, decency and moral Pancasila and endanger the community, nation and state when viewed from national interests. Gambling has a negative impact on the morale and mentality of the community, especially the younger generation.

Government Regulation of the Republic of Indonesia Number 9 of 1981 concerning the Implementation of Law Number 7 of 1974 concerning Control of Gambling, Article 1 paragraph (1), mentions several types of gambling namely casino gambling, gambling in a crowded place, and gambling which is associated with other reasons .

Gambling or gambling in Article 1 of Law Number 7 of 1974 concerning Control of Gambling is referred to as a gambling crime and is identical to crime, but the definition of gambling crime is basically not clearly stated and detailed either in the Criminal Code or in Law Number 71974 concerning Control of Gambling.

In Law No. 7/1974 concerning Gambling Control which changes the criminal threat in Article 303 of the Criminal Code with a severe criminal threat that is ten (10) years in prison and a fine of 25 million rupiah.

In the case of gambling, even though the threat of punishment has been exacerbated and the type of offense has been changed (from violation to crime), this community disease cannot be overcome. That is partly because humans have basic needs that must be met, while on the other hand not everyone can meet these needs for various reasons, for example because they do not have work or they may have work but not enough to meet their basic needs. So they do a variety of ways to increase the shortage of these needs, including the choice of gambling and gambling, gambling becomes an alternative that must be done even though they know the risks, to meet their needs and their families.

Based on the results of the study, it is known that there are many factors that cause someone to like playing gambling lottery. From some of these factors can be grouped into two factors, namely internal factors and external factors.

a. Internal factors, In general, internal factors are causes that originate within the lottery gambler, these factors include, among others, economic factors, educational factors, religious factors, and the belief in victory factors.

b. External factors, factors originating from outside the lottery gamblers themselves, these factors include, among others, social factors, environmental factors, and family factors.

These efforts include prevention and repressive measures.

a. Preventive efforts (prevention), preventive efforts that are intended as an effort to prevent the possibility of emergence and widespread gambling in the community, so trying to prevent someone before committing the crime of gambling, however prevention is still far better than cure.

b. Repressive efforts (countermeasures), Countermeasures are all efforts aimed at someone who has become evil to help him back the right path, so as not to repeat his actions. Countermeasures such as information from the public, investigations and investigations, ambushes, giving punishment or imposing penalties on violators, coaching in correctional institutions.

Lottery gambling which is considered prevalent in the Indonesian community, especially in the city of Semarang, indeed invites great enthusiasm among the people, not only the middle to lower classes, but also according to the source, this lottery gambling is quite popular with the middle to upper classes. In fact, if examined positively, this lottery gambling game is considered as a place to prove one's fortune, besides it is also profitable by only spending Rp. $1,000.00$ to buy a lottery number, then someone has the opportunity to earn money around Rp. 25,000, 00 up to Rp. $75,000,000.00$. Thus, crime can be seen as a human action and as a social phenomenon

Factors That Caused the Rise of Togel Gambling such as: religion, economic factors, 
education (level of education), environment (habist and customary), and the weaknesses of law enforcement.

\section{Declaration of Conflicting Interests}

The authors state that there is no potential conflict of interest in the research, authorship, and/or publication of this article

\section{Funding}

None

\section{References}

Arief, B. N. (1998). Beberapa Aspek Kebijakan Penegakan dan Pengembangan Hukum Pidana. Bandung: Citra Aditya Bakti.

Arief, B. N. (2010). Kebijakan Legislatif dalam Penanggulangan Kejahatan dengan Pidana Penjara. Yogyakarta: Genta Publishing.

Bonger, W.A. (1962). Inleiding tot de Criminologie, R.A. Koesnoen (trans). Pengantar Tentang Kriminologi. Pembangunan: Jakarta.

Dirdjosisworo, S. (1994). Sinopsis Kriminologi Indonesia. Bandung: Mandar Maju.

Gurvitch, G. (1961). Sociology of Law, Sumantri Mertodipuro (trans). Sosiologi Hukum. Jakarta: Barata.

Haryanto, H. (2003). Indonesia, Negara Judi? Jakarta: Yayasan Khasanah.

Kartono, K. (1981). Pathologi Sosial. Jakarta: Rajawali Pres

Kartono, K. (1992). Patologi Sosial 2 Kenakalan Remaja. Jakarta: Rajawali Pres.

Kelana, M. (1994). Hukum Kepolisian. Jakarta: Gramedia.

Kusuma, M. W. (1988). Kejahatan dan Penyimpangan. Jakarta: YLBHI.

Meier, R. F. (1977). The New Criminology: Continuity in Criminological Theory. The Journal of Criminal Law and Criminology, 4(7), 461-469. Retrieved from https://scholarlycommons.law.northwestern. edu/cgi/viewcontent.cgi?article $=6001 \&$ conte $\mathrm{xt}=\mathrm{jclc}$.

Moeljatno, M. (2002). Azas-Azas Hukum Pidana. Jakarta: Rineka Cipta.

Moliono, P. M. (1976). Criminology and Politicization, in C. W. G. Jaspers et. al. eds., Criminology: Between the Rule of Law and the Outlaws, Deventer: Kluwer.

Poerwadarminta, P. (1995). Kamus Besar Bahasa Indonesia, Edisi Kedua. Jakarta: Balai Pustaka.

Sahetapy, J. E. (1982). Parados Kriminologi. Jakarta: Rajawali Pers.

Saleh, W. (1976). Perlengkapan Kitab UndangUndang Hukum Pidana. Jakarta: Ghalia Indonesia.

Santoso, T., \& Zulfa, E. A. (2009). Kriminologi. Jakarta: Raja Grafindo Persada.

Sebayang, M. M. (2005). Tindak Pidana Perjudian dan Penanggulangannya di Wilayah

Tanah Karo. Thesis. Medan: Universitas Sumatera Utara.

Soekanto, S., Liklikuwata, H., Kusumah, M. W. (1986). Kriminologi Suatu Pengantar. Jakarta: Ghalia Indonesia.

Sudarsono, S. (2008). Kenakalan Remaja. Jakarta: Rineka Cipta

Sudarto, S. (1990). Hukum Pidana I. Semarang: Yayasan Sudarto.

Tabah, A. (1991). Menatap Dengan Mata Hati Polisi Indonesia. Jakarta: Gramedia Pustaka Utama.

Tangketasik, C. (2017). Peran Bhabinkamtibmas dalam Penanggulangan Tindak Pidana Perjudian di Wilayah Hukum Polres Magelang (Studi Pada Satuan Binmas Polres Magelang). Indonesian Journal of Police Studies, 1(4). Retrieved from http://journal.akpol.ac.id/index.php/ijps/artic le/view/52.

Tas, H. V. D. (1961). Kamus Hukum BelandaIndonesia. Jakarta: Timun Mas.

Tiyarto, S. (2006). Kebijakan Penegakan Hukum Pidana dalam Rangka Penanggulangan Perjudian. Thesis. Semarang: Universitas Diponegoro.

Utrecht, E. (1958). Hukum Pidana I. Jakarta: Universitas.

West, M. (1970). An International Reader's Dictionary. London: Longman Group Limited. 
Widhiantara, I. K. A, \& Suardana, I. W. (2013).

Upaya Hukum Penanggulangan Tindak

Pidana Perjudian Togel oleh Kepolisian di

Polresta Denpasar. Kertha Wicara: Journal

Ilmu Hukum,1(3), 1-5. Retrieved from https://ojs.unud.ac.id/index.php/kertha wicara/article/view/6164.

Submitted June 30, 2019

Revision received January 22, 2020

Accepted April 22, 2020

\section{How to cite?}

Rossa, N. O., Nurmalasari, R., Prameswari, L., \& Savella, A. D. (2020). Gambling (Judi Togel) in Criminology Perspective (Study in Diponegoro and Peterongan Stadium in Semarang City). Law Research Review Quarterly, 6(2), 157-172. https://doi.org/10.15294//rrq.v6i2.31111 


\section{Quote}

\section{In gambling the many must lose in order that the few may win.}

George Bernard Shaw 